\title{
DESIGN VALUE ENGINEERING IN KOREA
}

\author{
Sangwuk JI \\ Member of JSCE, Ph. D, Chief Research Engineer, Technical Policy Research Group, \\ Korea Institute of Construction Technology \\ (2311, Daehwa-dong, Ilsan-gu, Koyang-shi, Kyoungki-do, Korea)
}

\begin{abstract}
After IMF economic crisis, the great efforts have been made to break down the high-cost and low efficiency structure in Korean construction industry. Korean government introduced Design. VE Program to cope with that situation, connected with Technique Improvement Incentive Program and Budget Saving Incentive Program.

This paper is to review the present condition and drawbacks of those programs and design VE with several examples and to present recommendations to go on with Design VE program.
\end{abstract}

Key Words : design VE, technique improvement incentive program, budget saving incentive program.

\section{INTRODUCTION}

After IMF economic crisis in 1997 , the great efforts have been made at the all parts to break down the high-cost and low efficiency structure prevailing all over the Korean society. Especially in the construction industry, which takes the lead in the national economic development, the government has established and promoted the plan, "Comprehensive measures for public construction service efficiency", and private sector has striven to improve the service quality and reduce the construction cost.

As part of that, the government has enforced "Technique improvement incentive program" and "Budget saving incentive program", which have connection with the VE program at the design phase. And recently design VE program was adopted as an effective technique for reducing costs, increasing productivity and improving quality without adversely affecting a project. Before that, the implementation of the design VE was introduced on the "Comprehensive measures for public construction service efficiency" in 1999, and was specified on the law through the revision of "Enforcement ordinance of construction technology management law" this march.

This paper is to review the present conditions and drawbacks of current programs such as "Technique improvement incentive program", "Budget saving incentive program" and design VE with several examples and to present recommendations to go on with Design VE program.

\section{TECHNIQUE IMPROVEMENT INCENTIVE PROGRAM AND ACHIEVEMENTS}

(1) Technique Improvement Incentive Program

"Technique improvement incentive program" is provided in the law as follows; "Enforcement ordinance of national contract law", "General requirements of construction contract", and "Operational regulations on construction techniques development \& management" (Table 1).

This program encourages contractor to present new techniques and methods to save cost and time of the project, which leads to inspire the construction techniques improvement and to strengthen the competitiveness. After "Regulation on technique improvement incentive program procedure" was provided in 1992, it has been applied in earnest.

Table 1 History of Technique Improvement Incentive Program ${ }^{1)}$

\begin{tabular}{|l|l|}
\hline 1980.11 & $\begin{array}{l}\text { Contents } \\
\text { prescribed "Technique improvement incentive } \\
\text { budget financial law" (saving : government 50\%, } \\
\text { contractor 50\%) }\end{array}$ \\
\hline 1987.04 & $\begin{array}{l}\text { revised the law to make contractors eligible to } \\
\text { receive 100\% of the saving they generate }\end{array}$ \\
\hline 1992.02 & $\begin{array}{l}\text { provided Regulation on "Technique improvement } \\
\text { incentive program procedure" }\end{array}$ \\
\hline 1999.09 & $\begin{array}{l}\text { revised Article 65 of "Enforcement ordinance of } \\
\text { national contract law" (saving : government 50\%, } \\
\text { contractor 50\%) }\end{array}$ \\
\hline
\end{tabular}


Table 2 Outcome of Technique Improvement Incentive Program ${ }^{1)}$ (cost in million of won)

\begin{tabular}{|c|c|c|c|}
\hline No & Project & Applied Tech. & $\begin{array}{c}\text { Incen- } \\
\text { tive }\end{array}$ \\
\hline 1 & $\begin{array}{c}\text { JuAm dam waterworks by } \\
\text { Dong-Ah construction Corp. }\end{array}$ & Italy CIFA form & 290 \\
\hline 2 & $\begin{array}{c}\text { Pusan 2nd Urban Highway } \\
\text { construction by Daelim Corp. }\end{array}$ & $\begin{array}{c}\text { British RMD1 } \\
\text { span steel girder }\end{array}$ & 60 \\
\hline 3 & $\begin{array}{c}\text { Jinju city NaBul stream cover } \\
\text { construction by TaeYoung Corp. }\end{array}$ & $\begin{array}{c}\text { Transfer steel truss } \\
\text { timbering }\end{array}$ & 530 \\
\hline 4 & $\begin{array}{c}\text { The Yulchon industrial } \\
\text { complex fill-up construction in } \\
\text { ChuNam Prov. by HyunDai } \\
\text { Construction Corp }{ }^{2)}\end{array}$ & $\begin{array}{c}\text { Fill-up } \\
\text { construction } \\
\text { (Surface desiccation } \\
\text { treatment method) }\end{array}$ & 3,500 \\
\hline 5 & $\begin{array}{c}\text { Gym. roof steel beam } \\
\text { construction by DooSan const. }\end{array}$ & $\begin{array}{c}\text { Main truss }+\mathrm{H} \\
\text { rolled steel beam }\end{array}$ & 900 \\
\hline
\end{tabular}

After "Regulation on technique improvement incentive program procedure" was provided in 1992, total 5 cases were applied and net construction cost saving was estimated about 5.28 billion Won (Table 2).

But, there were some difficulties to make it use actively; limited application only to new techniques and methods and no incentive to the client who approved the proposal, while the contractor received $100 \%$ incentive.

Therefore, the relevant law was revised in 1999 that the extent of the application was expanded to the improved method, including techniques and equipments equivalent of government design in effect and function, and the saving should be allocated to go fifty-fifty with client and contractor like VECP (Value Engineering Change Proposal) in the U.S ${ }^{3}$.

To promote and activate the use of this program fairly, there are some problems to solve as follows;

a) Client side

Lack of incentive to the client authority

- weak influence on performance rating

\section{Concern about criticism by supervisor}

- happens the case that an official in charge doesn't pay saving to the contractor concerning about being blamed for insufficient review, which leads to change the design according to the proposed one.; in real condition, a proposed method is not approved except having severe difficulties with original project, because an official in charge want to avoid being reprimanded for wasting budget.

Lack of assurance and verification about safety and performance of proposed method

- difficulties in assuring the safety of new techniques and methods with lack of site work

Lack of standard of design, specification and wage in the case of new techniques and methods

- difficulties in preparing the statement of itemized costs without wage standard

- difficulties in preparing drawings without design and specification standard

\section{b) Contractor side}

Negative viewpoint of client authority

- lack of knowledge or misunderstanding of the full requirements of the original project plan

- risk associated with trying something that you have not tried before

- complexity of administrative process

\section{Complexity of required documents}

- it takes much time to prepare required documents including review of advantage/disadvantage by construction method, review of structure safety, detailed construction work plan, safety and management plan, quality management plan, detailed statement of itemized costs etc.

\section{Complexity of approval process}

- it takes time more than 1 month (more than 2 months under the committee) or additional endeavor and time if delayed or required more documents; happens the case that an official in charge at client authority persuades contractor not to submit the proposals or overlooks the change of construction method without any process.

\section{(2) Budget Saving Incentive Program}

"Budget saving incentive program" has put in force on the basis of ' 98 estimated expenditure execution guide to encourage officials to save budget voluntarily since May in 1998. This program offers an opportunity to present suggestions, such as labor cut, program improvement and new system introduction, without sacrificing the quality of the project and receive the financial benefit (Table 3 ).

After the implementation, 9 authorities saved about 12.7 billion won and received about 4.3 billion won in 1998, 9 authorities saved 32.4 billion won and received about 4.2 billion won in the first half 1999 (Table 4).

Looking over the results of "Budget saving incentive program" by each authority in the second half of 1999 (Table 5), there were 268 cases approved in 10 authorities by the Ministry of Planning and Budget. The MOCT showed remarkable records compared to other authorities, saved totally 12 billion won and received 191 million won as an incentive from the Ministry of Planning and Budget.

Table 3 Content of Budget Saving Incentive Program ${ }^{\text {1) }}$

\begin{tabular}{|c|c|c|}
\hline Content & Incentive & Post Adjustment \\
\hline labor cut & $\begin{array}{c}\text { as much as annual } \\
\text { salary of labor cut }\end{array}$ & $\begin{array}{c}\text { reflect the total reduced } \\
\text { labor costs }\end{array}$ \\
\hline operating cost & $50 \%$ of saving & reflect $30 \%$ of saving \\
\hline $\begin{array}{c}\text { main project } \\
\text { cost }\end{array}$ & $\begin{array}{c}10 \% \text { of saving(less than } \\
100 \text { million won per case) }\end{array}$ & reflect saving \\
\hline $\begin{array}{c}\text { revenue } \\
\text { increase }\end{array}$ & $\begin{array}{c}10 \% \text { of increased } \\
\text { revenue }\end{array}$ & \\
\hline
\end{tabular}


Table 4 Outcome of Budget Saving Incentive Program

(Costs in billion of won)

\begin{tabular}{|c|c|c|c|c|}
\hline FY & $\begin{array}{c}\text { Authorities } \\
\text { (cases) }\end{array}$ & Saving & Incentive & Remarks \\
\hline 1998 & $\begin{array}{c}9 \\
(12)\end{array}$ & 12.7 & 4.3 & - \\
\hline $\begin{array}{c}1999 \\
\text { (the first half) }\end{array}$ & $\begin{array}{c}9 \\
(14)\end{array}$ & 32.4 & 4.2 & - \\
\hline $\begin{array}{c}1999 \\
\text { (the second } \\
\text { half) }\end{array}$ & $\begin{array}{c}10 \\
(268)\end{array}$ & $1,816.4$ & 6.8 & $\begin{array}{c}\text { including the } \\
\text { increased } \\
\text { revenue }\end{array}$ \\
\hline
\end{tabular}

Otherwise, as a result of reviewing the affiliated authorities of the MOCT in the budget saving cases symposium, which have striven to save budget and work efficiently in 1999 , totally 630.6 billion won was saved through the changes and the improvement of construction method, on average 27.4 billion won per case (Table 6) ${ }^{1)}$. Some of the cases presented in the symposium were not applicable to "Budget saving incentive program". Those examples are as cases of cost control by Korea Land Corporation, business improvement by Korea National Housing Corporation, etc.

This can be estimated to present some models for the future in public construction service and budget work by visualizing the outcome which has resulted from institutional support such as "Compre- hensive measures for public construction service efficiency", "Technique improvement incentive program" and "Budget saving incentive program".

But, the most of the cost-effective projects, as stated above, are limited to the execution phase rather than initial phase like planning and design, at which the project scope and cost are under consideration. The design phase with careful analysis and investigation can conduce to reduce the cost and improve the quality of project by reducing unnecessary changes. But we place less weight on it than other developed countries do. It is said to result from lack of legal basis, systematic procedure and its guidelines and awareness about importance of saving at the initial phase.

\section{DESIGN VALUE ENGINEERING ${ }^{4)}$}

In 1999, the government promoted the introduction of Design VE program to raise the efficiency in public construction services. As part of that, a study on "Implementation of design VE in construction" was performed by Korea Institute of Construction Technology with financial support of the Ministry of Construction \& Transportation. The guidelines of design VE presented by our research team are as follows.

Table 5 Budget savings by authority in 1999(the second half) (Costs in millions of Wons)

\begin{tabular}{|c|c|c|c|c|}
\hline \multirow{2}{*}{ Authority } & \multirow{2}{*}{ No. } & \multirow{2}{*}{ Savings \& Benefit } & \multicolumn{2}{|c|}{ Incentive } \\
\hline & & & Submitted & Approved \\
\hline \multicolumn{5}{|l|}{$<$ Budget savings $>$} \\
\hline Ministry of National Defense & 5 & 5,956 & 82 & 76 \\
\hline $\begin{array}{l}\text { Ministry of Government } \\
\text { Administration } \\
\text { and Home Affairs }\end{array}$ & 3 & 730 & 72 & 53 \\
\hline Ministry of Agriculture and Forestry & 1 & 379 & 40 & 29 \\
\hline Ministry of Labor & 2 & 89 & 9 & 9 \\
\hline $\begin{array}{c}\text { Ministry of Construction \& } \\
\text { Transportation }\end{array}$ & 18 & 12,018 & 867 & 191 \\
\hline $\begin{array}{l}\text { Ministry of Maritime Affairs and } \\
\text { Fisheries }\end{array}$ & 4 & 375 & 121 & 54 \\
\hline $\begin{array}{c}\text { Ministry of Patriots \& Veterans } \\
\text { Affairs }\end{array}$ & 2 & 587 & 295 & 6 \\
\hline Public Procurement Service & 1 & 251 & 25 & 23 \\
\hline Subtotal & 36 & 20,385 & 1,511 & 441 \\
\hline \multicolumn{5}{|l|}{$<$ Benefit $>$} \\
\hline National Tax Service & 214 & $1,785,688$ & 26,100 & 6,215 \\
\hline Korea Customs Service & 15 & 8,791 & 183 & 117 \\
\hline $\begin{array}{c}\text { - Ministry of Government } \\
\text { Administration and Home } \\
\text { Affairs } \\
\text { - Ministry of Maritime Affairs and } \\
\text { Fisheries } \\
\text { - Public Procurement Service }\end{array}$ & 3 & 1,537 & 86 & 13 \\
\hline Subtotal & 232 & $1,794,4791,794,479$ & 26,369 & 6,345 \\
\hline Total & 268 & $1,816,401$ & 27,880 & 6,786 \\
\hline
\end{tabular}


Table 6 Budget savings of 12 affiliated authorities of the MOCT (costs in million of won)

\begin{tabular}{|c|c|c|c|c|}
\hline $\begin{array}{l}\text { Affiliated } \\
\text { Authority }\end{array}$ & Contents & $\begin{array}{l}\text { Initial } \\
\text { project } \\
\text { cost } \\
\end{array}$ & $\begin{array}{l}\text { Revised } \\
\text { project } \\
\text { cost }\end{array}$ & Savings \\
\hline $\begin{array}{c}\text { Seoul regional } \\
\text { construction } \\
\text { management office }\end{array}$ & Budget savings of construction cost (2cases) & 60,900 & 52,800 & 8,100 \\
\hline \multirow{2}{*}{$\begin{array}{c}\text { Wonju regional } \\
\text { construction } \\
\text { management office }\end{array}$} & $\begin{array}{l}\text { Project cost savings by SaBuk } 2 \text { Tunnel pit mouth } \\
\text { expansion and adjustment }\end{array}$ & 264,000 & 262,736 & 1,264 \\
\hline & $\begin{array}{l}\text { Project cost savings by longitudinal profile } \\
\text { adjustment }\end{array}$ & 76,442 & 75,974 & 468 \\
\hline $\begin{array}{l}\text { Daejeon regional } \\
\text { construction } \\
\text { management office }\end{array}$ & Budget savings by bridge slab form improvement & 285 & 178 & 107 \\
\hline $\begin{array}{c}\text { Iksan regional } \\
\text { construction } \\
\text { management office }\end{array}$ & $\begin{array}{l}\text { Project cost savings by improvement of L-gutter } \\
\text { construction method }\end{array}$ & 64,299 & 35,814 & 28,485 \\
\hline \multirow{2}{*}{$\begin{array}{c}\text { Pusan regional } \\
\text { construction } \\
\text { management office }\end{array}$} & $\begin{array}{l}\text { by structure improvement of bridge inspection } \\
\text { way }\end{array}$ & 46 & 41 & 5 \\
\hline & by selecting dumping yard at a short distance & 3,416 & 1,850 & 1,566 \\
\hline $\begin{array}{l}\text { Pusan Regional } \\
\text { Aviation } \\
\text { Administration }\end{array}$ & $\begin{array}{l}\text { Supervision cost savings at navigation safety } \\
\text { facility construction }\end{array}$ & 7,871 & 7,638 & 233 \\
\hline $\begin{array}{l}\text { Korea Highway } \\
\text { Corporation }\end{array}$ & $\begin{array}{l}\text { Central inland highway section } 8 \text { turnkey project } \\
\text { budget savings \& function enlargement by } \\
\text { changing profile }\end{array}$ & 193,500 & 188,000 & 5,500 \\
\hline $\begin{array}{l}\text { Korea Land } \\
\text { Corporation } \\
\end{array}$ & by cost control ( 5 cases) & $3,886,434$ & $3,356,187$ & 530,220 \\
\hline \multirow{2}{*}{$\begin{array}{l}\text { Korea Water } \\
\text { Resources } \\
\text { Corporation }\end{array}$} & 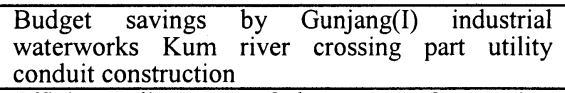 & 127,718 & 121,501 & 6,217 \\
\hline & $\begin{array}{l}\text { Efficient adjustment of the extent of removing } \\
\text { trees around reservoir in Nam river dam. }\end{array}$ & 846,800 & 844,610 & 2,190 \\
\hline \multirow[t]{2}{*}{$\begin{array}{c}\text { Korea National } \\
\text { Housing Corporation }\end{array}$} & $\begin{array}{l}\text { unit cost savings and business improvement } \\
\text { through integration of fire extinguishing } \\
\text { equipments }\end{array}$ & 359,849 & 355,793 & 4,056 \\
\hline & $\begin{array}{l}\text { Deregulation and emergency water supply } \\
\text { facilities improvement for environment protection }\end{array}$ & $1,310,400$ & $1,308,800$ & 1,600 \\
\hline \multirow{2}{*}{$\begin{array}{l}\text { Incheon International } \\
\text { Airport Corporation }\end{array}$} & Budget savings at airport's landscape project & 26,941 & 11,400 & 15,541 \\
\hline & $\begin{array}{l}\begin{array}{l}\text { Construction cost savings by pavement test } \\
\text { construction }\end{array} \\
\end{array}$ & 276,746 & 268,892 & 7,854 \\
\hline \multirow{2}{*}{$\begin{array}{l}\text { Korea High Speed } \\
\text { Rail Construction } \\
\text { Authority } \\
\end{array}$} & Budget savings by the use of the recycled & 571 & 7 & 564 \\
\hline & $\begin{array}{l}\text { Project cost savings by changes of structure } \\
\text { (protection wall) }\end{array}$ & 75,000 & 58,400 & 16,600 \\
\hline Total & & $7,581,218$ & $6,950,621$ & 630,597 \\
\hline
\end{tabular}

\section{(1) Selection of project for VE study}

It is prescribed by an "Enforcement ordinance of construction technology and management law" that the Design VE is required on construction projects, that are exceeding 50 billion won in total cost, involving new techniques or special techniques or requested by client and that it should be carried out by experts such as design supervisors etc.

As an object of the Design VE based on this among domestic construction projects, there are approximately 320 cases a year including under way now, and 30 to 40 cases a year for new projects including turn-key contract. This means that there are not much projects requiring Design VE except turn-key contract.

It's quite reckless to introduce foreign system unconditionally without any analysis. Therefore, following the example of Japan, we suggest that the VE implementation should be performed on large scale construction first of all, which usually provides the highest potential for the VE, then gradually expand its selection. This type of projects are: major structures, with remarkable techniques improvements possible, and with crucial constraints, difficult technical issues or complicated functional requirements.

\section{(2) Team composition}

A Value Engineering study is made by a multidisciplined team whose objective is to investigate/ analyze the design of an existing project; to analyze project functions and costs; to creatively speculate on alternative ways to perform the various functions, to evaluate the best and/or least life-cycle alternatives; to develop acceptable alternatives into fully supported recommendations; and to present the team's recommendations to management. Therefore, contractors should 
not apply the VE to their own designs to maximize its effect.

In the U.S., only except the State of Washington, it is usual for the designers excluded on VE team. It causes low implementation rate $(28 \%)$ of recommendation on account of designer's big resistance against VE team's proposal.

Whereas in case of the State of Washington, the rate raised $82 \%$ after putting designer in VE team as a member.

Therefore, it is desirable that according to the circumstances of the project a client use own discretion to have project designer in the VE team or not; with designer to implement the recommendations effecttively through the communication between them, without designer to maximize the effect of the VE. Even a designer who is not a member of the VE team should be in coordination and cooperation with them by providing relevant data and presenting the information of the project etc.

As a general rule, client should take responsibility for the VE study and appoint the VE coordinator who takes lead to the team. In addition, because it is on the initial stage of introduction, more than one expert from other agencies should be invited to participate as team members on a case by case basis depending on project issues.

\section{(3) Selection of team members}

The VE team should be comprised of any person meeting the minimum requirements for certification with diverse backgrounds relevant to the specific study like design, execution, supervision and management. To that end, the process of selecting team members should be established to assess the qualification from all angles of work results, capability and experience.

It is strongly recommended that in the beginning it is focused on overall sides because of lack of qualified VE practitioners. As it is just getting under way, detailed selection criteria based on experience in performing and leading the VE studies should be necessary.

\section{(4) The VE implementation}

The timing of the VE implementation is critical to the success of the project programming and development to maximize its efficiency. In fact, the earlier VE study applied, the greater the potential saving. Because the project scope and cost are under consideration at the conceptual phase (Fig.1)

But since proper timing for optimum results can be different from each project according to the circumstances, it is undesirable to be regulated by law.

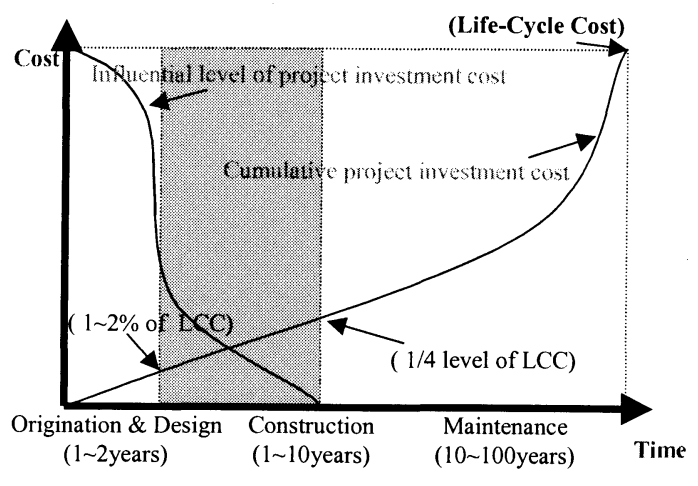

Fig.1 Investment scale by stage

Instead, the client can usually ensure that specific VE studies can be accomplished without conflicting with the project schedule and there are more than one potential window of opportunity for accomplishing the VE study on preliminary design and execution design respectively.

\section{(5) Labor cost criteria}

The current labor cost standard of the engineering service part is calculated on the basis of percentage of construction cost and cost-plus fixed fee method, which is applicable to service of design and supervision, feasibility study, master plan set up, traffic influence evaluation, close safety inspection and safety management plan. Since the service of the $\mathrm{VE}$ is similar with those, it is reasonable to calculate the VE staff labor cost on the basis of cost-plus fixed fee method. Also it's quite similar with American method based on man-day.

But, in that case, as shown in Table 7, the results of calculations are 5 to 8 times less than the VE staff labor cost used in the U.S. method.

The current standard calculation of labor cost is deterrent to activate the VE program. To promote broad acceptance and use of the VE, it is necessary to adopt proper measures such as an incentive through institutional support, moreover, which should enable foreign engineers to participate through separate contract for the effective progress of the VE study and its technical innovation ${ }^{5)}$.

\section{(6) Evaluation of recommendations of VE team}

Unlike the U.S., we are not accustomed to make a decision through discussion with others. So it's not effective for the project designer to take charge of reviewing and evaluating the recommendations made by the VE team, because the VE study is regarded as a kind of risk which makes it hard to reach an amicable agreement fairly. Therefore, the process should be conditional on the participation of all the relevant parties such as the client, the VE team 


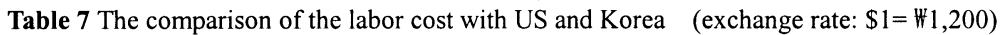

\begin{tabular}{|c|c|c|c|c|c|c|}
\hline \multicolumn{3}{|c|}{ U.S. VE staff labor cost(A) } & \multicolumn{3}{|c|}{$\begin{array}{l}\text { Domestic engineer labor cost(B) } \\
\text { (cost-plus fixed fee method) }\end{array}$} & \multirow{2}{*}{$\begin{array}{l}\text { Remarks } \\
\text { (A/B) }\end{array}$} \\
\hline VE team & $\begin{array}{l}\text { labor cost } \\
(\$ / \text { day) }\end{array}$ & $\begin{array}{l}\text { total cost } \\
(\mathbb{W} / 10 \text { days })\end{array}$ & Engineer & $\begin{array}{l}\text { labor cost } \\
\text { (W/day) }\end{array}$ & $\begin{array}{l}\text { total cost } \\
\text { (W/10days) }\end{array}$ & \\
\hline $\begin{array}{c}\text { Leader } \\
\text { (PE/CVS) }\end{array}$ & 1,387 & $16,644,000$ & Professional & 173,852 & $2,955,484$ & 5.6 \\
\hline Other PE/CVS & 1,040 & $12,480,000$ & $\begin{array}{l}\text { Special/high } \\
\text { Grade }\end{array}$ & $\begin{array}{c}109,695 \sim \\
132,166\end{array}$ & $\begin{array}{l}1,864,815 \sim \\
2,246,822\end{array}$ & 6.1 \\
\hline Team members & 925 & $11,100,000$ & $\begin{array}{l}\text { Middle/Primary } \\
\text { Grade }\end{array}$ & $\begin{array}{c}65,947 \sim \\
91,968\end{array}$ & $\begin{array}{l}1,121,099 \sim \\
1,563,456\end{array}$ & 8.2 \\
\hline notes) & & Engineer, C & S: Certified Valu & $\begin{array}{l}\text { Specialist } \\
\text { use it takes }\end{array}$ & Ans & $\begin{array}{l}\text { ation a } \\
\text { ding }\end{array}$ \\
\hline
\end{tabular}

members and the designer. And if it doesn't work itself out somehow, it is recommended that the appropriate third party like a design advisory committee should take it over.

In addition, the revision of the design should be performed by the project designer like other foreign countries, and the following additional cost should be paid through separate contract.

\section{CONCLUSIONS}

Recently developed countries like the U.S and Japan have promoted and encouraged the use of Design VE to accomplish public construction services more effectively, leading to allocate limited resources without reducing the quality of a project.

Mostly, the cost-effective projects in Korea, as stated above, are limited to the execution phase. It means that the introduction of the VE program at the design phase and its guidelines are keenly required for greater potential cost saving.

So far, I have tried out to introduce the reasonable system appropriate to the domestic circumstances, taking the U.S. and Japan as a benchmark through the projects launched by the MOCT. And it is thought that design VE techniques can be used to ensure project quality, to eliminate unnecessary costs and to improve the value in nearly every aspect of the construction projects.

But, to apply the VE in construction effectively, lots of efforts should be focused on training engineers and establishing relevant database prior to its imple- mentation itself.

Moreover, since the recent construction project tends to increase construction time and cost according to its large-scale and complexity and the durability of structure itself becomes longer, the importance of cost analysis is emphasized at the all stage of the construction. Therefore, it is recommended that LifeCycle Cost method should be introduced gradually, of which concept includes all parts such as plan, design, execution, maintenance and management, repair and dismantlement.

\section{REFERNECES}

1) Ministry of Construction and Transportation: Budget saving cases symposium in construction part, Korea Institute of Construction Technology, pp.13 15, p.21, 1999. 12. 17.

2) Ministry of Construction and Transportation: Comprehensive measures for public construction service efficiency, Korea Institute of Construction Technology, p.280, 1999. 7.

3) International Construction Technology Association: Construction VE, p.258, 1998. 5.

4) Korea Institute of Construction Technology: A scheme of introducing VE for construction projects, p.122, 2000. 9.

5) Kim.W.J., Park.K.H.: VE in Japanese Business, Korea Management Association, 1986.

6) Hujita Technology Headquarters VE Promoting Division: Practical application of construction VE, Shongokusha, 1977.

7) Japan Society of Civil Engineers: A study on the VE application to the public construction project, 1996.

(Received March 6, 2001) 